\title{
The utility of lung epithelium specific biomarkers in cardiac surgery: a comparison of biomarker profiles in on- and off-pump coronary bypass surgery
}

Gerwin E Engels ${ }^{1 *}$, Y John Gư ${ }^{2}$, Willem van Oeveren ${ }^{1,2}$, Gerhard Rakhorst ${ }^{3}$, Massimo A Mariani ${ }^{2}$ and Michiel E Erasmus ${ }^{2}$

\begin{abstract}
Background: Despite continuous improvements in materials and perfusion techniques, cardiac surgery still causes lung injury and a delay of pulmonary recovery. Currently, there is no gold standard for quantifying cardiac surgery induced lung injury and dysfunction. Adding objective measures, such as plasma biomarkers, could be of great use here. In this study the utility of lung epithelium specific proteins as biomarkers for lung dysfunction was evaluated.

Methods: Serial measurements of plasma concentrations of Clara cell 16 kD (CC16) protein, Surfactant protein D (SP-D), Elastase and Myeloperoxidase were performed on blood samples from 40 patients who underwent coronary artery bypass grafting with cardiopulmonary bypass $(C A B G, n=20)$ or without cardiopulmonary bypass (OPCAB, $n=20)$.

Results: The increase of SP-D and CC16 between pre-operative concentrations and concentrations at the end of cardiopulmonary bypass, correlated with the Aa- $\mathrm{O}_{2}$ gradient at 1 hour on the ICU $\left(R_{\mathrm{s}}=0.409, p=.016\right.$ and $R_{\mathrm{s}}=0.343$, $p=.043$, respectively).

Furthermore, SP-D and CC16 were higher in CABG than in OPCAB at the end of surgery [8.96 vs. $4.91 \mathrm{ng} / \mathrm{mL}, p=.042$ and 92 vs. 113\%, $p=.007$, respectively]. After $24 \mathrm{~h}$ both biomarkers returned to their baseline values.

Conclusions: Our results show that increases in plasma of SP-D and CC16 correlate with clinical lung injury after coronary artery bypass surgery. Therefore, lung epithelium specific proteins seem to be a useful biomarker for measuring lung injury in the setting of cardiac surgery.
\end{abstract}

Keywords: Clara cell 16 kD protein, Surfactant protein D, Cardiopulmonary bypass, Off-pump, CABG

\section{Background}

Despite continuous improvements in materials and perfusion techniques, cardiac surgery still causes lung injury and a delay of pulmonary recovery $[1,2]$. This delay can partly be attributed to the unique aspects of cardiac surgery, such as the sternotomy, cardioplegia, and the use of cardiopulmonary bypass (CPB). Pulmonary dysfunction following cardiac surgery varies between hypoxemia to acute respiratory distress syndrome. Currently, there is no gold standard for quantifying cardiac surgery induced lung injury and dysfunction. A vast series of physiological

\footnotetext{
* Correspondence: gerwinengels@gmail.com

'HaemoScan B.V, Groningen, The Netherlands

Full list of author information is available at the end of the article
}

changes (alveolar-arterial oxygen pressure difference, lung compliance, pulmonary vascular resistance, etc.) and measurement of lung unspecific inflammation markers such as neutrophil elastase, and myeloperoxidase [1] have been reported.

The use of lung epithelium specific secretory proteins for evaluating the integrity of the alveolar capillary membrane has been proposed as an alternative method to assess lung injury [3]. For instance, variations in plasma concentrations of surfactant proteins (surfactant protein A and D) were associated with sepsis, respiratory distress syndrome and interstitial lung diseases [4]. Recently, a surfactant protein has been used as a marker for lung injury after surgery with $\mathrm{CPB}[5]$. 
Clara cells, mainly located in the (terminal) bronchioles, are responsible for protecting the bronchiolar epithelium, by detoxifying inhaled substances and secreting the anti-inflammatory Clara Cell $16 \mathrm{kD}$ protein (CC16) [6]. Serum concentrations of CC16 have been associated with injury of the alveolar-capillary membrane, and are nowadays often used as a biomarker of injury to the alveolar-capillary membrane in different models $[7,8]$.

The utility of these lung epithelium specific proteins as biomarkers for lung dysfunction in the setting of cardiac surgery is unknown. To explore this, we performed serial measurements of surfactant protein D and CC16 in a patient group undergoing elective coronary bypass surgery either with or without the use of cardiopulmonary bypass. It was expected that the use of CPB during coronary bypass surgery would result in more lung dysfunction [9], and consequently higher plasma concentrations of lung epithelium specific proteins. Secondly, the aim was to analyse if there was a correlation between these lung epithelium specific proteins and lung dysfunction. Lung dysfunction was assessed by the $\mathrm{PaO}_{2} /$ $\mathrm{FiO}_{2}$ ratio and the alveolar-arterial oxygen pressure gradient ( $\mathrm{Aa}-\mathrm{O}_{2}$ gradient) on the ventilator on the intensive care unit (ICU).

\section{Methods}

\section{Study subjects and design}

Patient material from a previous study investigating the role of $\mathrm{CPB}$ on RBC aggregation and deformability was used [10]. Forty patients with indication for coronary surgery were prospectively included after approval from the local institutional review board and informed consent from each individual. Patients were randomly allocated to a group operated with cardiopulmonary bypass (CABG, $n=20$ ) or without (OPCAB, $n=20$ ). The inclusion criterion for the study was first time CABG. Exclusion criteria were emergency surgery, significantly impaired ventricular function $(\mathrm{EF}<35 \%)$ or a previous cerebrovascular accident.

For all patients, anaesthesia was induced and maintained by the intravenous infusion of midazolam and sufentanil followed by a median sternotomy. In the CABG group, CPB was performed with a heart-lung machine consisting of roller pumps and a membrane oxygenator with integrated heat exchanger. During CPB, moderate hypothermia $\left(34^{\circ} \mathrm{C}\right)$ was applied with a pump flow of $2.4 \mathrm{~L} / \mathrm{min} / \mathrm{m}^{2}$. Whole body anticoagulation was achieved with $300 \mathrm{IU} /$ ( $\mathrm{kg}$ body weight) heparin in CABG patients and $100 \mathrm{IU} /$ (kg body weight) heparin in OPCAB patients.

For patients undergoing CABG, blood samples of $10 \mathrm{~mL}$ were taken immediately after the induction of anaesthesia but before surgery (PRE-OP), 5 minutes after start of surgery (START-OP), 5 minutes after the whole body heparinisation (HEPARIN), 5 minutes after start of CPB and haemodilution (START CPB/30' HEP), 15 minutes after end of CPB (END CPB/ANASTOMOSIS), one hour after surgery ( $1 \mathrm{~h} \mathrm{ICU}$ ), and on the first postoperative morning (24 h ICU). For the OPCAB patients, the sampling time was similar to the CABG patients, except for START CPB/30' HEP and END CPB/ANASTOMOSIS, which were taken 30 minutes after heparinisation and 15 minutes after the end of coronary anastomosis, respectively. Blood gas samples were taken one hour after surgery $(1 \mathrm{~h} \mathrm{ICU})$. Each blood sample was anticoagulated with $0.1 \mathrm{mM}$ EDTA. Plasma was obtained by centrifugation of whole blood at $1100 \times \mathrm{g}$ for $10 \mathrm{~min}$. Hereafter, plasma was aliquoted and stored at $-80^{\circ} \mathrm{C}$ for later analysis.

\section{Determination of surfactant protein $D$}

Surfactant protein D plasma concentration as a marker of alveolar-capillary membrane integrity was measured in plasma by means of sandwich ELISA. Capture and detection antibodies were from R\&D Systems (R\&D Systems, Minneapolis, USA). Recombinant human Surfactant protein D (R\&D Systems, Minneapolis, USA) served as a standard. Inter- and intra-assay coefficient of variation were $4.4 \%$ and $2.6 \%$, respectively.

\section{Determination of Clara cell $16 \mathrm{kD}$ protein}

Clara cell 16 protein (CC16), a marker of respiratory epithelial integrity, was measured by sandwich ELISA. Recombinant human CC16 (R\&D Systems, Minneapolis, USA) served as a standard. A monoclonal rat antibody to human CC16 (R\&D Systems, Minneapolis, USA) was used as a capture antibody and monoclonal mouse antibody to human CC16 (Hycult, Uden, The Netherlands) was used as a detection antibody. Inter- and intra-assay coefficient of variation were $5.6 \%$ and $4.8 \%$, respectively.

\section{Determination of elastase- $a_{1}$-antitrypsin complex}

Elastase plasma concentration as a marker of leukocyte activation was determined by means of sandwich ELISA. Antibodies were purchased from Affinity Biologicals (Affinity Biologicals Inc., Ancaster, Canada). Elastase isolated from human donor leukocytes (Merck KGaA, Darmstadt, Germany) served as a standard. Inter- and intra-assay coefficient of variation were $6.3 \%$ and $5.2 \%$, respectively.

\section{Determination of myeloperoxidase (MPO)}

MPO plasma concentration as another marker of leukocyte activation was also determined by means of sandwich ELISA. Capture and detection antibodies were purchased from Hytest (HyTest LTD, Turku, Finland). Myeloperoxidase isolated from human donor leukocytes 
(HyTest LTD, Turku, Finland) served as a standard. Inter- and intra-assay coefficient of variation were $8.6 \%$ and $6.5 \%$, respectively.

\section{Data analysis}

Biochemical measurements were corrected for hemodilution by using hematocrit levels. All values are summarized as mean and standard deviation, or median and interquartile range in case the data were non-normally distributed. The Student's t-test was used to compare means of continuous variables, whereas the MannWhitney $\mathrm{U}$ test was used for non-normally distributed variables. Correlations were assessed with Spearman rank correlation tests. Contingency tables, $\chi^{2}$ and Fisher exact tests were used as appropriate. A two-way mixed ANOVA was used to compare serial data. Violations of sphericity were Greenhouse-Geisser corrected. All tests performed in order to test the (null-) hypothesis of no difference were two-sided. A $p$-value $<.05$ was considered statistically significant. Statistical analyses were performed with SPSS version 16.0 for Windows (SPSS Inc., Chicago, Ill, United States).

\section{Results}

Forty patients scheduled for elective cardiac surgery were included in this study. Patient characteristics are described in Table 1. There were no significant differences between the groups with regard to relevant baseline characteristics, except for the number of diabetic patients in the OPCAB group, which was less than in the CABG group.

In the CABG group, SP-D plasma concentration (Figure 1A) was significantly increased at the end of surgery (END CPB/ANASTOMOSIS) as compared with the OPCAB group [8.96 vs. $4.91 \mathrm{ng} / \mathrm{mL}$ (median), $p=.042$ ] One day after surgery ( $24 \mathrm{~h} \mathrm{ICU),} \mathrm{SP-D} \mathrm{plasma} \mathrm{concentra-}$ tion returned to baseline values. In the OPCAB group median SP-D plasma concentration remained constant during the procedure.

To compare between groups, interindividual differences in CC16 plasma concentration made it necessary to normalize $\mathrm{CC} 16$ values by means of the baseline measurement: $\mathrm{CC}_{1} 6_{\mathrm{i} \_ \text {normalized }}=\mathrm{CC}_{16} / \mathrm{CC}_{\mathrm{i}} 6_{\text {Baseline }} \times$ $100 \%$. Data before normalization are summarized in Table 2. During cardiopulmonary bypass CC16 plasma concentration increased in the CABG group whereas there was no increase in the OPCAB group (Figure 1B). Plasma concentrations returned to baseline values on the first postoperative day ( $24 \mathrm{~h} \mathrm{ICU}$ ).

Elastase was measured as an index of leukocyte activation (Table 2). After reperfusion (END CPB/ANASTOMOSIS) elastase markedly increased in the CABG group and was significantly higher than in the $\mathrm{OPCAB}$ group [29.1 vs. $4.0 \mu \mathrm{g} / \mathrm{mL}$ (median), $p<.001]$. At one hour after surgery $(1 \mathrm{~h} \mathrm{ICU})$ this difference was even
Table 1 Baseline characteristics and operative variables

\begin{tabular}{lccc}
\hline Variable & $\begin{array}{c}\text { CABG } \\
(n=20)\end{array}$ & $\begin{array}{c}\text { OPCAB } \\
(n=20)\end{array}$ & $p$ value $^{a}$ \\
\hline
\end{tabular}

Baseline characteristics

\begin{tabular}{lccc}
\hline Age [years] & \multicolumn{3}{c}{0.857} \\
\hline Mean & 9 & 11 & \\
\hline SD & & & 0.487 \\
\hline Length [cm] & 174 & 172 & \\
\hline Mean & 6 & 8 & \\
\hline SD & & & 0.536 \\
\hline Weight [kg] & 81 & 79 & \\
\hline Mean & 11 & 12 & \\
\hline SD & & & 0.168 \\
\hline Gender [No.] & $16(80 \%)$ & $12(60 \%)$ & \\
\hline men & & & \\
\hline Coexisting illness [No.] & 5 & 0 & 0.047 \\
\hline Diabetes & 3 & 1 & 0.605 \\
\hline Pulmonary disease & & & \\
\hline Postoperative variables & & & $<0.001$ \\
\hline Operation time [min] & 205 & 126 & \\
\hline Mean & 31 & 49 & \\
\hline SD & &
\end{tabular}

\begin{tabular}{lcll}
\hline Cross clamb time $[\mathrm{min}]$ & & & \\
\hline Mean & 51 & - & \\
\hline SD & 16 & - & \\
\hline CPB time $[\mathrm{min}]$ & & & \\
\hline Mean & 81 & - & \\
\hline SD & 22 & - & \\
\hline Creatinine clearance $[\mu \mathrm{mol} / \mathrm{L}]$ & & & \\
\hline Mean & 76.3 & 79.2 & \\
\hline SD & 14.6 & 25.3 & \\
\hline Ventilation time $[\mathrm{h}]$ & & & \\
\hline Mean & 13.7 & 5.1 & \\
\hline SD & 7.5 & 7.1 & \\
\hline PaO2/FiO2 [mmHg] & & & \\
\hline Median & 189 & 238 & \\
\hline IQR & $163-264$ & $214-272$ & \\
\hline Aa-O2 gradient $[\mathrm{mmHg}]$ & & & \\
\hline Median & 159 & 137 \\
\hline IQR & $137-172$ & $116-153$ \\
\hline
\end{tabular}

a Student's t-test, Mann-Whtiney $\mathrm{U}$ test, $\mathrm{x} 2$ or Fisher excact test used as appropriate.

larger [37.7 vs $5.1 \mu \mathrm{g} / \mathrm{mL}$ (median), $p<.001]$. On the first postoperative day ( $24 \mathrm{~h} \mathrm{ICU}$ ) elastase plasma concentration in the CABG group returned to baseline whereas it was moderately increased in the OPCAB group.

Myeloperoxidase concentration, another maker for leukocyte activation, increased in both groups after whole body heparinisation (Table 2), however MPO plasma 
concentration was significantly higher in the CABG group as compared with the OPCAB group [507 vs. $360 \mathrm{ng} / \mathrm{mL}$ (median), $p=.002]$. One day after surgery MPO plasma concentration returned to baseline values in both groups.

Two-way mixed ANOVA revealed an overall increase for SP-D, MPO and Elastase in the CABG group as compared to the OPCAB group $(p=.014, p<.001$ and $p<.001$, respectively), CC16 also showed an increase although not statistically significant $(p=.068)$.

At 1 hour after surgery ( $1 \mathrm{~h} \mathrm{ICU}$ ) lung function as assessed by $\mathrm{PaO}_{2} / \mathrm{FiO}_{2}$ was better in the OPCAB group as compared to the CABG group (Table 1). Analogously, the $\mathrm{Aa}-\mathrm{O}_{2}$ gradient was significantly lower in the OPCAB group. Our data show an association between the net increase in SP-D $(\triangle$ SP-D, SP-D at $1 \mathrm{~h}$ ICU minus SP-D at PRE-OP) and $\mathrm{PaO}_{2} / \mathrm{FiO}_{2}$ (Table 3). Similarly, there is an association between $\Delta$ SP-D and the $\mathrm{Aa}-\mathrm{O}_{2}$ gradient.

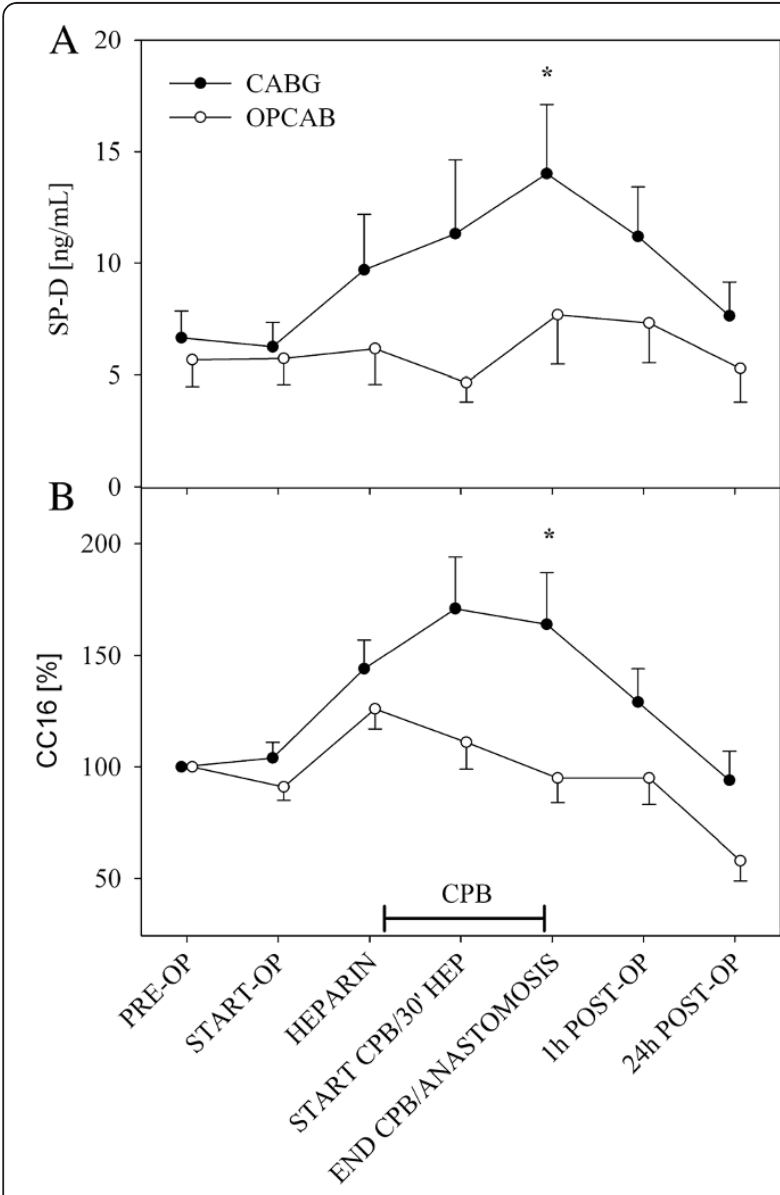

Figure 1 A) Surfactant protein D plasma concentrations. Data shown are mean \pm SEM of SP-D plasma concentrations measured by ELISA in CABG and OPCAB patients (Overall $p=.014$ ). B) CC16 plasma concentrations. Data shown are mean \pm SEM of CC16 plasma concentrations measured by ELISA in CABG and OPCAB patients (Overall $p=.068$ ). Closed and open circles represent CABG and $\mathrm{OPCAB}$, respectively. ${ }^{*} p<.05$ CABG versus OPCAB.
The normalized values of $\mathrm{CC} 16$ at the end of cardiopulmonary bypass (END CPB/ANASTOMOSIS) depicted a similar association with $\mathrm{PaO}_{2} / \mathrm{FiO}_{2}$ (Table 3) and the $\mathrm{Aa}-\mathrm{O}_{2}$ gradient.

Since SP-D and Elastase showed similar trends during the coronary bypass surgery procedure, their relation after reperfusion (END CPB/ANASTOMOSIS) was analysed. The two variables exhibited a significant association (Figure 2, Spearman's rho $=0.548, p=.001$ ).

\section{Discussion}

This study shows that SP-D and CC16 are sensitive markers of lung injury and that they can be useful in the setting of cardiac surgery. After CABG, with or without $\mathrm{CPB}$, higher SP-D and CC16 plasma concentrations were associated with more lung injury as assessed by the $\mathrm{PaO}_{2} / \mathrm{FiO}_{2}$ ratio and the $\mathrm{Aa}-\mathrm{O}_{2}$ gradient early on the ICU. Secondly, higher SP-D and CC16 plasma concentrations after $\mathrm{CABG}$ with $\mathrm{CPB}$ as compared to $\mathrm{OPCAB}$ were found.

The use of lung epithelium specific proteins for describing lung injury is attractive because there are hardly any direct lung injury markers available. To our knowledge only the group of Boven et al. has utilised this before by measuring CC16 and KL-6 (Krebs von den Lungen-6) for comparing standard $\mathrm{CPB}$ with a mini extracorporeal circuit [11]. They found that $\mathrm{CC} 16$ is a potential biomarker for damage to the alveolar capillary membrane during coronary artery bypass surgery.

There are several hypotheses for explaining the increase of lung epithelium specific proteins, 1) increased permeability of the alveolar capillary membrane, 2) increased production or secretion of these proteins, or 3 ) decreased renal clearance [12].

The increase in elastase plasma concentration, and its association with $\triangle \mathrm{SP}-\mathrm{D}$, supports the notion of increased permeability of the alveolar capillary membrane after $\mathrm{CPB}$, a well-described phenomenon caused by an inflammation reaction induced by $\mathrm{CPB}$. This reaction includes activation of the coagulation cascade, the complement system and release of cytokines and adhesion receptors which results in neutrophil-endothelial cell interactions that liberate lung macrophage proteases and neutrophilic enzymes, such as elastase, and produce diffuse tissue injury and increased pulmonary vascular permeability $[2,13]$. It is well known that elastase has multiple effects on the respiratory epithelium; one of them is the reduction in integrity of the epithelium by cleaving $\mathrm{E}$ cadherin [14]. Furthermore, the increase in elastase represents leukocyte activation, which also results in generation and release of reactive oxygen species [15]. Reactive oxygen species contribute to a decrease in pulmonary endothelial barrier function by disrupting 
Table 2 Biomarker plasma concentrations

\begin{tabular}{|c|c|c|c|c|c|c|c|c|c|c|}
\hline \multirow[b]{2}{*}{ Variable } & \multirow[b]{2}{*}{ Pre-op } & \multirow[b]{2}{*}{ Start-op } & \multirow[b]{2}{*}{ Heparin } & \multirow[b]{2}{*}{ Start CPB/30' Hep } & \multirow[b]{2}{*}{ End $\mathrm{CPB} /$ Anastomosis } & \multirow[b]{2}{*}{$1 \mathrm{~h} \mathrm{ICU}$} & \multirow[b]{2}{*}{$24 \mathrm{~h} \mathrm{ICU}$} & \multicolumn{3}{|c|}{$p$ values $^{\mathrm{a}}$} \\
\hline & & & & & & & & $\begin{array}{c}\text { Between } \\
\text { groups }\end{array}$ & $\begin{array}{l}\text { Between } \\
\text { timepoints }\end{array}$ & Interaction \\
\hline \multicolumn{2}{|c|}{ SP-D [ng/mL] - Median (IQR) } & & & & & & & 0.068 & 0.001 & 0.014 \\
\hline CABG & $4.15(2.88-7.99)$ & $4.71(2.83-7.92)$ & $4.59(3.00-13.36)$ & $6.20(3.19-13.44)$ & $8.96(7.32-14.12)$ & $8.71(5.25-13.91)$ & $5.69(2.99-11.46)$ & & & \\
\hline OPCAB & $4.39(1.97-8.08)$ & $3.51(2.67-6.95)$ & $4.27(2.61-6.75)$ & $4.14(2.48-5.26)$ & $4.91(2.07-10.72)$ & $5.08(3.43-7.39)$ & $3.99(0.59-6.72)$ & & & \\
\hline \multicolumn{2}{|c|}{ CC16 [ng/mL] - Median (IQR) } & & & & & & & 0.988 & $<0.001$ & 0.068 \\
\hline CABG & $5.41(4.38-9.21)$ & $6.45(4.25-9.45)$ & $8.15(5.88-13.56)$ & $10.36(6.18-16.79)$ & $10.47(6.50-14.34)$ & $7.95(4.33-13.23)$ & $4.66(3.92-9.18)$ & & & \\
\hline OPCAB & $5.14(5.59-15.06)$ & 7.95 (4.79-11.09) & $10.61(7.62-14.02)$ & $8.33(6.22-11.64)$ & $8.34(5.64-13.42)$ & $7.15(4.57-14.50)$ & $3.92(2.28-7.43)$ & & & \\
\hline \multicolumn{2}{|c|}{ Elastase $[\mu \mathrm{g} / \mathrm{mL}]$ - Median (IQR) } & & & & & & & 0.002 & $<0.001$ & $<0.001$ \\
\hline CABG & $2.16(1.63-3.19)$ & $1.87(1.61-3.46)$ & $2.68(2.03-3.13)$ & $4.09(2.32-4.95)$ & $29.1(14.3-2.24)$ & $37.7(14.0-55.9)$ & $16.7(7.63-24.6)$ & & & \\
\hline OPCAB & $1.43(1.17-2.85)$ & $2.17(1.61-3.46)$ & $2.12(1.25-2.86)$ & $2.89(2.12-3.47)$ & $4.02(2.24-4.90)$ & $5.13(3.13-6.95)$ & $12.9(7.97-20.9)$ & & & \\
\hline \multicolumn{2}{|c|}{ MPO [ng/mL] - Median (IQR) } & & & & & & & 0.025 & $<0.001$ & $<0.001$ \\
\hline CABG & $37(28-45)$ & $28(23-48)$ & $441(334-527)$ & $507(401-571)$ & $191(133-310)$ & $134(80-170)$ & $52(45-58)$ & & & \\
\hline OPCAB & $41(32-50)$ & $38(32-45)$ & $367(314-386)$ & 360 (319-388) & $172(101-304)$ & 109 (64-148) & $59(48-80)$ & & & \\
\hline
\end{tabular}


Table 3 Correlation between lung biomarkers and $\mathrm{PaO}_{2} /$ $\mathrm{FiO}_{2}$ and $\mathrm{Aa}-\mathrm{O}_{2}$ gradient at $1 \mathrm{~h}$ ICU

\begin{tabular}{lcccc}
\hline & $\mathrm{PaO}_{2} / \mathrm{FiO}_{2}[\mathrm{mmHg}]$ & \multicolumn{2}{c}{$\mathrm{Aa}-\mathrm{O}_{2}$ gradient $[\mathrm{mmHg}]$} \\
\hline & $\mathrm{Rs}$ & $\boldsymbol{p}$-value & $\mathrm{Rs}$ & $\boldsymbol{p}$-value \\
\hline SP-D $[\mathrm{ng} / \mathrm{mL}]$ & 0.462 & .006 & 0.409 & .016 \\
\hline CC16 [\%] & 0.342 & .044 & 0.343 & .043 \\
\hline
\end{tabular}

intercellular tight junctions and redistribution of focal adhesions [16].

Another explanation for higher lung epithelium specific proteins levels might be an increased production or secretion of these proteins in the bronchioli and alveoli after $\mathrm{CPB}$, suggesting a protective function of these lung proteins. This is supported by a three-fold increase of SP-B and SP-C in tracheal aspirates after surgery with $\mathrm{CPB}$ in children [17]. Literature does not provide reference values for $\mathrm{CC} 16$ in bronchoalveolar lavage fluid (BALF) after cardiac surgery. However, Determan et al. analysed CC16 plasma and BALF concentrations following various surgical procedures to compare the influence of two mechanical ventilation strategies. The authors compared CC16 concentrations directly after intubation and after $5 \mathrm{~h}$ of surgery and they found an increase in plasma concentrations but not in BALF concentrations [18]. This supports the explanation of increased permeability rather than increased production or secretion.

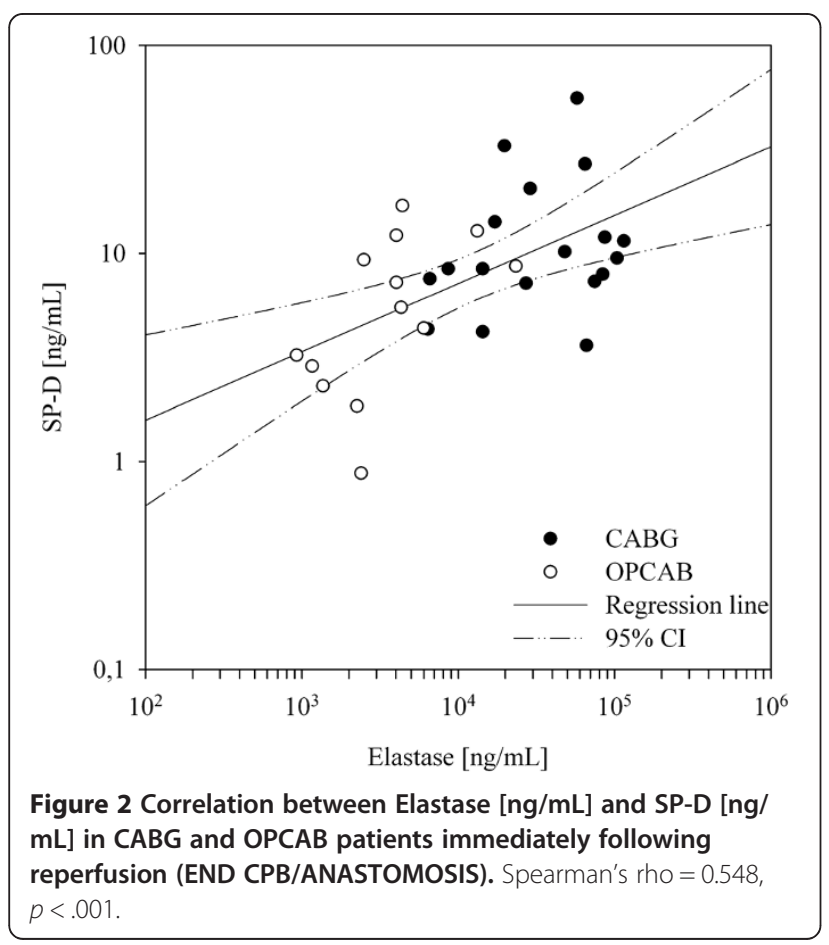

Whether higher concentrations of lung epithelium specific proteins in the epithelium lining fluid lead to higher plasma concentrations without an increased permeability is not clear. Perhaps only a larger concentration gradient between alveoli and circulation is sufficient for increasing plasma concentrations. Our finding that plasma concentrations of lung epithelium specific proteins returned to baseline $24 \mathrm{~h}$ after surgery (paralleled by elastase plasma concentrations) suggests a temporary increase in permeability of the alveolar capillary membrane.

The third possible explanation for increased plasma concentration of lung epithelium specific proteins is decreased renal function. Although there is always some degree of decreased renal function following CABG, about $7 \%$ decrease in creatinine clearance in a recent study [19], this small decrease is not likely responsible for the increase in SP-D and CC16. Moreover, we found no difference in creatinine clearance between groups, but we did find higher concentrations of lung epithelium specific proteins in the CABG group.

Our second finding was the reduction of lung epithelium specific proteins in the OPCAB group. OPCAB is known to reduce the inflammatory reaction as compared to CABG with $\mathrm{CPB}[20,21]$. Therefore, it may be expected that $\mathrm{OPCAB}$ can reduce the occurrence of diffuse tissue injury and a reduced leakage of lung epithelium specific proteins.

The benefits of preventing clinical lung injury and/or dysfunction by OPCAB are still debated; there are studies that report better gas exchange after OPCAB [22] and others that do not [23-25]. These results are based on clinical parameters such as the gradient between inspired oxygen concentration and arterial blood oxygen tension. Possibly these parameters are not sensitive enough to detect injury to the alveolar capillary membrane in low risk patients with relatively short operation times. The use of lung epithelium specific biomarkers can be of use, as we were able to show an increase in SP-D and CC16 plasma concentrations in the CABG group. This may explain the finding that OPCAB significantly reduced pulmonary complications such as ventilation time and pneumonia and also a shorter ICU stay and 30 day mortality in a recent study by others [26].

Myeloperoxidase, which is considered as a measure for the activation of neutrophils, increased right after the administration of heparin. This profile of MPO during $\mathrm{CPB}$ surgery has been reported before [27], and it can be explained by heparin-induced liberation of endothelial bound MPO [28]. Moreover, the liberation of MPO seems to be dose dependent as the CABG group reveived three times more heparin than the OPCAB group. Altogether, these observations suggest that MPO might not be a good biomarker for activation of neutrophils in the setting of CPB. 


\section{Conclusions}

We have shown that higher SP-D and CC16 plasma concentrations correlate with more clinical lung injury after coronary bypass surgery. Furthermore, the CABG group had higher SP-D and CC16 plasma concentrations and more lung injury as compared with the OPCAB group. Lung epithelium specific proteins seem to be a useful biomarker for measuring lung injury and can be used for assessing strategies meant to reduce CPB-induced lung injury.

\section{Competing interests}

The authors declare that they have no competing interests.

\section{Authors' contributions}

YG, WVO and ME conceived and designed the study. GE performed the measurements, analysis and drafted the manuscript. All authors were involved in the interpretation of the data, revised the article critically, and gave their final approval of the version to be published.

\section{Acknowledgements}

The authors would like to thank Fonds NutsOhra for their financial support.

\section{Author details}

${ }^{1}$ HaemoScan B.V, Groningen, The Netherlands. ${ }^{2}$ Department of Cardiothoracic Surgery, University of Groningen, University Medical Center Groningen, Groningen, The Netherlands. ${ }^{3}$ Department of Surgery, University of Groningen, University Medical Center Groningen, Groningen, The Netherlands.

Received: 25 September 2012 Accepted: 7 January 2013

Published: 9 January 2013

\section{References}

1. Ng CSH, Wan S, Yim APC, Arifi AA: Pulmonary dysfunction after cardiac surgery. Chest 2002, 121:1269-1277.

2. Wan S, LeClerc J-L, Vincent J-L: Inflammatory response to cardiopulmonary bypass: mechanisms involved and possible therapeutic strategies. Chest 1997, 112:676-692.

3. Hermans C, Bernard A: Lung epithelium-specific proteins: characteristics and potential applications as markers. Am J Respir Crit Care Med 1999, 159:646-678.

4. Sorensen GL, Husby S, Holmskov U: Surfactant protein A and surfactant protein D variation in pulmonary disease. Immunobiology 2007. 212:381-416.

5. Agostoni $\mathrm{P}$, Banfi $\mathrm{C}$, Brioschi M, Magrì D, Sciomer S, Berna G, et al: Surfactant protein $B$ and RAGE increases in the plasma during cardiopulmonary bypass: a pilot study. Eur Respir J 2011, 37:841-847.

6. Pilette C, Godding V, Kiss R, Delos M, Verbeken E, Decaestecker C, et al Reduced epithelial expression of secretory component in small airways correlates with airflow obstruction in chronic obstructive pulmonary disease. Am J Respir Crit Care Med 2001, 163:185-194.

7. Diamond JM, Kawut SM, Lederer DJ, Ahya VN, Kohl B, Sonett J, et al: Elevated plasma clara cell secretory protein concentration is associated with high-grade primary graft dysfunction. Am J Transplant 2011, 11:561-567.

8. Determann RM, Millo JL, Waddy S, Lutter R, Garrard CS, Schultz MJ: Plasma CC16 levels are associated with development of ALI/ARDS in patients with ventilator-associated pneumonia: a retrospective observational study. BMC Pulm Med 2009, 9:49.

9. e Silva AMRP, Saad R, Stirbulov R, Rivetti LA: Off-pump versus on-pump coronary artery revascularization: effects on pulmonary function. Interact Cardiovasc Thorac Surg 2010, 11:42-45.

10. Gu YJ, Graaff R, de Hoog E, Veeger NJGM, Panday G, Boonstra PW, et al: Influence of hemodilution of plasma proteins on erythrocyte aggregability: an in vivo study in patients undergoing cardiopulmonary bypass. Clin Hemorheol Microcirc 2005, 33:95-107.
11. van Boven W-JP, Gerritsen WBM, Zanen P, Grutters JC, van Dongen HPA, Bernard A, et al: Pneumoproteins as a lung-specific biomarker of alveolar permeability in conventional on-pump coronary artery bypass graft surgery vs mini-extracorporeal circuit: a pilot study. Chest 2005 127:1190-1195.

12. Lakind JS, Holgate ST, Ownby DR, Mansur AH, Helms PJ, Pyatt D, et al: A critical review of the use of clara cell secretory protein (CC16) as a biomarker of acute or chronic pulmonary effects. Biomarkers 2007 . 12:445-467

13. Miller $B E$, Levy JH: The inflammatory response to cardiopulmonary bypass. J Cardiothorac Vasc Anesth 1997, 11:355-366.

14. Ginzberg HH, Cherapanov V, Dong Q, Cantin A, McCulloch CA, Shannon PT, et al: Neutrophil-mediated epithelial injury during transmigration: role of elastase. Am J Physiol Gastrointest Liver Physiol 2001, 281:G705-G717.

15. Arnhold J, Flemmig J: Human myeloperoxidase in innate and acquired immunity. Arch Biochem Biophys 2010, 500:92-106.

16. Usatyuk PV, Natarajan V: Regulation of reactive oxygen species-induced endothelial cell-cell and cell-matrix contacts by focal adhesion kinase and adherens junction proteins. Am J Physiol Lung Cell Mol Physiol 2005, 289:L999-L1010.

17. Friedrich B, Schmidt R, Reiss I, Günther A, Seeger W, Müller M, et al: Changes in biochemical and biophysical surfactant properties with cardiopulmonary bypass in children. Crit Care Med 2003, 31:284-290.

18. Determann RM, Wolthuis EK, Choi G, Bresser P, Bernard A, Lutter R, et al: Lung epithelial injury markers are not influenced by use of lower tidal volumes during elective surgery in patients without preexisting lung injury. Am J Physiol Lung Cell Mol Physio 2008, 294:L344-L350.

19. Elmistekawy E, Chan V, Bourke ME, Dupuis J-Y, Rubens FD, Mesana TG, et al: Off-pump coronary artery bypass grafting does not preserve renal function better than on-pump coronary artery bypass grafting: results of a case-matched study. J Thorac Cardiovasc Surg 2012, 143:85-92.

20. Nesher N, Frolkis I, Vardi M, Sheinberg N, Bakir I, Caselman F, et al: Higher levels of serum cytokines and myocardial tissue markers during onpump versus off-pump coronary artery bypass surgery. J Card Surg 2006 21:395-402.

21. Greilich PE, Brouse CF, Rinder HM, Jessen ME, Rinder CS, Eberhart RC, et al: Monocyte activation in on-pump versus off-pump coronary artery bypass surgery. J Cardiothorac Vasc Anesth 2008, 22:361-368.

22. Staton GW, Williams WH, Mahoney EM, Hu J, Chu H, Duke PG, et al: Pulmonary outcomes of off-pump vs on-pump coronary artery bypass surgery in a randomized trial. Chest 2005, 127:892-901.

23. Groeneveld ABJ, Jansen EK, Verheij J: Mechanisms of pulmonary dysfunction after on-pump and off-pump cardiac surgery: a prospective cohort study. I Cardiothorac Surg 2007, 2:11.

24. Montes FR, Maldonado JD, Paez S, Ariza F: Off-pump versus on-pump coronary artery bypass surgery and postoperative pulmonary dysfunction. J Cardiothorac Vasc Anesth 2004, 18:698-703.

25. Cimen S, Ozkul V, Ketenci B, Yurtseven N, Günay R, Ketenci B, et al: Daily comparison of respiratory functions between on-pump and off-pump patients undergoing CABG. Eur J Cardiothorac Surg 2003, 23:589-594.

26. Kerendi F, Halkos ME, Puskas JD, Lattouf OM, Kilgo P, Guyton RA, et al: Impact of off-pump coronary artery bypass graft surgery on postoperative pulmonary complications in patients with chronic lung disease. Ann Thorac Surg 2011, 91:8-15.

27. Quaniers JM, Leruth J, Albert A, Limet RR, Defraigne J-O: Comparison of inflammatory responses after off-pump and on-pump coronary surgery using surface modifying additives circuit. Ann Thorac Surg 2006, 81:1683-1690.

28. Baldus S, Rudolph V, Roiss M, Ito WD, Rudolph TK, Eiserich JP, et al: Heparins increase endothelial nitric oxide bioavailability by liberating vessel-immobilized myeloperoxidase. Circulation 2006, 113:1871-1878.

\section{doi:10.1186/1749-8090-8-4}

Cite this article as: Engels et al.: The utility of lung epithelium specific biomarkers in cardiac surgery: a comparison of biomarker profiles in onand off-pump coronary bypass surgery. Journal of Cardiothoracic Surgery 2013 8:4. 